\title{
The Influence of Utilization of Information and Communication Technology, Career Development and Work Environment on Teacher Job Stress in SDN Cluster 1 and 3 Bandar Subdistrict, Bener Meriah Regency, Aceh Province
}

\author{
Nuri Nikmatin ${ }^{1}$, Darwin ${ }^{2}$, Sukarman Purba ${ }^{3}$ \\ \{raihanlingga95@gmail.com, 2darwin.dbep@gmail.com,3arman_prb@yahoo.com\} \\ ${ }^{1}$ Teacher at SMP 1 Takengon \\ ${ }^{2,3}$ Postgraduate Lecturers in Education Administration Department, State University of Medan
}

\begin{abstract}
This study aims to find out: the direct effect of Utilizing Information and Communication Technology on Career Development; the direct effect of Utilizing Information and Communication Technology on the Work Environment; the Direct Effects of the Use of Information and Communication Technology on Teacher's Job Stress; the direct effect of Career Development on teacher's Job Stress; the direct effect of the Work Environment on teacher's Job Stress. This research was conducted at SD Negeri 1 Cluster 1 and Cluster 3 Bandar Subdistrict. The study population was 193 teachers and the total sample was 123 teachers using Issac and Michael tables, with a sampling technique using Proportional Random Sampling. Data collection was carried out using a questionnaire, after an instrument trial was conducted to 40 teachers outside the sample. The data analysis technique used consisted of descriptive analysis, analysis requirements test, and path analysis with a significance level of 0.05 . The results of this study indicate the Utilization of Information and Communication Technology has a positive direct effect on teacher career development, Utilization of Information and Communication Technology has a direct positive effect on the Work Environment, Utilization of Information and Communication Technology has a negative direct effect on Job Stress, Career Development has a negative direct effect on Job Stress, and Work Environment has a direct negative effect on Job Stress. To reduce the level of teacher work stress can be done by increasing the utilization of information and communication technology, career development and work environment of teachers is getting better. The greatest effect on Job Stress Teachers is the variable Utilization of Information and Communication Technology, followed by Career Development and Work Environment.
\end{abstract}

Keywords: Utilization of information, communication technology, career development, work environment, teacher job stress

\section{Introduction}

Job stress is a deviant condition experienced by individuals in a work environment where there is an imbalance between the ability of an individual and the demands of a job that exceeds his ability. In working, the potential to experience stress is quite high, among others, can be caused by tension in interacting with superiors, jobs that require high concentration, 
workloads that are not in accordance with capacity, conditions of work environment that are not supportive, severe and unhealthy competition. This is in accordance with Gibson and James (1987) that work stress is an adjustment response, mediated by individual differences or psychological processes, which are the consequences of every action from outside (environment), situation, or event that determines the demand for psychology or physically excessive to someone [1]. In the general sense of work stress is a tension that affects emotions, thought processes, and one's physical condition. According to Kyriacou (2007), stated that teachers who experience stress during their duties and experience negative emotions such as anger, anxiety, tension, disappointment and moodiness are a threat to physical and psychological happiness. Based on the above theories, it can be concluded that the teacher's work stress is the stress that occurs in a teacher due to work, and the stress of teacher work occurs because of an imbalance between the ability of the teacher and the demands of the tasks assigned to them. Teacher work stress is characterized by characteristics: Experiencing excessive anger; Experiencing frustration; Experiencing excessive anxiety; Depressed and Experiencing anxiety. Job stress factors according to the National Safety Council (2004) are in the form of lack of autonomy, workload, job relocation, lack of training, karis development, poor relations with superiors, technological developments, increasing responsibi-lities without salary increases, and sacrificed workers (organizational factors), conflicts between career and family responsibilities, economic uncertainty, lack of job appreciation, work saturation, child care, and conflict with colleagues (individual factors), poor working environment conditions, sexual harassment, workplace violence, traffic jams when leaving and home work and racial discrimination (environmental factors) [2].

The reason for the use of information and communication technology (ICT) as a factor that influences teacher work stress is based on the results of preliminary observations conducted on 15 November to 15 December 2017 on 15 teachers in SD Negeri Groups 1 and 3 of Bandar Subdistrict. It is known that $73.3 \%$ of teachers experience work stress which is caused by the low ability of teachers to use information and communication technology. This is seen from: (1) many teachers are still unable to operate / use laptops and computers, causing teachers to be unable to fill out the revised 2013 Curriculum report 2017 which has been applied in the odd semester of the 2017/2018 academic year, causing teachers to pay other people's services to fill out the report cards. (2) many teachers are still unable to make PTK as a requirement in promotion or class, causing teachers to be late in proposing group increases. (3) many teachers are still unable to use learning tools sourced from the internet because of the inability to use computers / laptops, causing teachers to only apply learning with the lecture system.

The low effort of teachers in developing careers can be seen from: (1) the number of teachers who arrange teaching devices when they are going to rise in rank or class and when school accreditation is assessed; (2) teacher awareness to attend and leave school on time, and there is still a lack of awareness to get used to working seriously in accordance with applicable regulations, both workplace regulations and regulations that are made together as a guideline for carrying out daily activities at school; (3) The lack of interest and willingness of teachers to explore up-to-date learning resources from the internet or books and other sources; (4) The lack of the creative nature of the teacher in developing or utilizing the environment as a learning medium for students.

The school environment is not conducive, these problems arise in SD Negeri 1 and 3 schools in Bandar Subdistrict, including narrow classrooms so that the ratio between the number of students is not balanced with the size of the classroom. The narrow layout will cause a high temperature in the room, causing ineffective teaching and learning activities. In 
addition to spatial and temperature management, the cleanliness of the school environment is still lacking due to a lack of awareness of students in maintaining cleanliness.

\section{Methodology}

This research was conducted in SD Negeri Cluster 1 and 3 of Bandar Subdistrict, Bener Meriah District, Aceh Province. The study began in April to May 2018. The population for this study were all elementary school teachers in Cluster 1 and 3 of Bandar Subdistrict, Bener Meriah Regency, Aceh Province with criteria: status as Government Employees (PNS) and honorary, and not in MPP status. Based on these criteria, the total population in this study was 193 teachers spread across SD Negeri 1 and 3 in Bandar Subdistrict consisting of 16 schools. To determine the number of samples the study was conducted using the table Issac and Michael with a level of error of $5 \%$, if the total population is 193 people the number of samples is 123 .

The data collection technique in this study is to make research instruments in the form of: Teacher Job Stress Instruments; Instruments for Using Information and Communication Technology; Career Development Instruments; Work Environment, and then conducted an instrument trial. Tests were conducted on teachers who were not included in the sample but were still classified in the study population. The method taken is to give a questionnaire to the teachers of SD Negeri 1 and 3 Bandar Subdistrict which consists of 40 teachers outside the sample. To determine whether or not the questionnaire is used, it must be tested for the validity and reliability of the questionnaire. Valid and reliable are two important requirements to determine the goodness of an instrument. And then tested the validity and reliability. Besides, there are some terms must be understood related to this theme, and so-called as a literature review, as follows.

\subsection{Work Stress Essence}

According to Siagian (2014) defines that stress is one of the factors that influence a person's emotions, thoughts, and physical condition [3]. Stress that cannot be overcome properly usually results in the inability of people who interact positively with their environment, both in the work environment and outside environment. Adjectives that will be used for various negative variations that occur in work performance. Whereas according to Hardjana (1994), interpreting stress as a condition or condition that is created when the transaction of people who are stressed and people who cause the people involved to see the incompatibility between conditions and conditions and psychological, psychological and social resources that exist. In simple terms, Anoraga defines the stress a person does, both physically and mentally, in terms of perceived and threatened environment.

According to Robbins, the causes of work stress are grouped into three sources, namely factors originating from the environment, organization and individuals where large grouping is similar to grouping the causes of work stress by the National Safety Council [4] however, not the same in classifying factors more detailed. More detailed causes of work stress according to the National Safety Council (2004) are in the form of lack of autonomy, workload, job relocation, lack of training, karis development, poor relations with superiors, technological developments, increased responsibili-ties without salary increases, and workers who sacrificed (organizational factors), conflict between career and family responsibilities, economic uncertainty, lack of work appreciation, work saturation, child care, and conflict with 
colleagues (individual factors), poor working environment conditions, sexual abuse, workplace violence, congestion when leaving and returning to work and racial discrimination (environmental factors).

According to [9]define usefulness as a level where one believes that the use of a particular technology will improve the person's performance. Measurement of utilization is based on the frequency and diversity of technology used. Whereas according to [8] utilization can be in the form of the utilization of one factor such as work easier, useful, increasing productivity, effectiveness and improving job performance.

\subsection{Career development}

Stone (in Saydam) says career development is a process and activity to prepare an employee to occupy a position in an organization or company, which will be carried out in the future [5]. With this development, the definition of the company or HR manager has been compiled prior planning about the ways that need to be done to develop the employee's career while working. Furthermore, [8] suggested that career development is an employee's personal efforts to achieve a career plan. Furthermore, Samsudin stated that career development is a series (sequence) of positions / positions occupied by someone during a certain lifetime. Based on the description, the following is stated that this definition places the position / position of an employee in an organization's environment, as part of a series of positions / positions he occupies during his life [6]. [8]argues that career development is the process of improving individual work abilities achieved in order to achieve the desired career.

\subsection{Work Environment}

The work environment consists of work systems, job design, working conditions, and ways in which people are treated at work with their managers and coworkers. According to Nitisemito (1996), everything that exists around workers and can affect them in carrying out tasks that are charged [7]. [6], defines the work environment as a whole tool tool and material faced, the surrounding environment in which a person works, the method of work, and work arrangements both as individuals and as a group [8]. Meanwhile according to [9], which defines the work environment as a whole work infrastructure that exists around employees who are carrying out work that can affect the implementation of the work itself [5]. According to Nitisemito, argues that the indicators of the work environment are work atmosphere, relationships with colleagues, relations between subordinates and leaders, availability of facilities for employees [7]

\section{Result and Discussion}

\subsection{Data Description}

Data collected from 123 respondents were then analyzed descriptively by each variable by calculating the value of the central tendency and the size of its spread.

Table 1. Summary of Results of Analysis of Descriptive Statistics of Research Variables

\begin{tabular}{ccccc}
\hline Variabels & $\begin{array}{c}\text { UICT } \\
\left(\mathbf{X}_{\mathbf{1}}\right)\end{array}$ & $\begin{array}{c}\text { C.Development } \\
\left(\mathbf{X}_{\mathbf{2}}\right)\end{array}$ & $\begin{array}{c}\text { W.E } \\
\left(\mathbf{X}_{\mathbf{3}}\right)\end{array}$ & $\begin{array}{c}\text { Stress } \\
\left(\mathbf{X}_{\mathbf{4}}\right)\end{array}$ \\
\hline $\mathrm{N} \quad$ Valid & 123 & 123 & 123 & 123 \\
\hline
\end{tabular}




\begin{tabular}{lcccc}
\hline Mean & 89.01 & 98.21 & 114.02 & 115.93 \\
Median & 90.00 & 99.00 & 115.00 & 116.00 \\
Mode & 91 & 99 & 115 & 119 \\
Deviation & 7.607 & 11.017 & 10.169 & 11.976 \\
Standard & & & & \\
Variance & 57.861 & 121.381 & 103.417 & 143.429 \\
Range & 36 & 51 & 47 & 53 \\
Minimum & 69 & 70 & 90 & 89 \\
Maximum & 105 & 121 & 137 & 142 \\
Sum & 10948 & 12080 & 14025 & 14259 \\
Minimum & 23 & 26 & 30 & 32 \\
Ideal & & & & \\
Maximum & 115 & 130 & 150 & 160 \\
Ideal & & & & \\
Mean Ideal & 69 & 78 & 90 & 96 \\
Ideal & 15,33 & 17,33 & 20,00 & 21,33 \\
Deviation & & & & \\
Standard & & & & \\
\hline
\end{tabular}

Information:

UICT : Utilization of Information and Communication Technology $\left(\mathrm{X}_{1}\right)$

CD : Career Development $\left(\mathrm{X}_{2}\right)$

WE : Work Environment $\left(\mathrm{X}_{3}\right)$

Stress : Teacher's Job Stress $\left(\mathrm{X}_{4}\right)$

\subsection{Measurement of Input Analysis}

In quantitative research with a path analysis approach, as explained in the methodology section that before the analytical technique chosen to test the research hypothesis, it is necessary to examine the requirements of the analysis.

\subsubsection{Normality Test}

Table 2. Summary of Data Normality Test with the Kolmogorov-Simirnov Test

\begin{tabular}{llcccc} 
& & $\mathrm{X}_{1}$ & $\mathrm{X}_{2}$ & $\mathrm{X}_{3}$ & $\mathrm{X}_{4}$ \\
\hline $\mathrm{N}$ & & 123 & 123 & 123 & 123 \\
Normal & Mean & 89.01 & 98.21 & 114.02 & 115.93 \\
Parameters & & & \\
& Std. & 7.607 & 11.017 & 10.182 & 11.976 \\
& Deviation & & & & \\
Most Extreme & Absolute & .075 & .057 & .083 & .058 \\
Differences & Positive & .062 & .057 & .083 & .058 \\
& Negative & -.075 & -.055 & -.069 & -.048 \\
Kolmogorov-Smirnov Z & .830 & .630 & .922 & .643 \\
Asymp. Sig. (2-tailed) & .496 & .822 & .363 & .803 \\
\hline
\end{tabular}

Information:

$\mathrm{X}_{1}=$ Use of Information and Communication Technology

$\mathrm{X}_{2}=$ Career development

$\mathrm{X}_{3}=$ Work environment

$\mathrm{X}_{4}=$ Job stress 


\subsubsection{Linearity Test and Meaning of Regression Equations}

Table 3. Summary of Linearity Test and Meaning Test

\begin{tabular}{cccccccc}
\hline & Exogenous variable against & \multicolumn{3}{c}{ Linearity Test } & \multicolumn{3}{c}{ Regression Meaning Test } \\
\cline { 3 - 8 } No & Endogenous variable & $\mathrm{F}_{\mathrm{h}}$ & Sig. & Status & $\mathrm{F}_{\mathrm{h}}$ & Sig. & Status \\
\hline 1 & $\mathrm{X}_{1}$ with $\mathrm{X}_{2}$ & 1,419 & 0,103 & Linier & 43,279 & 0,000 & Significant \\
2 & $\mathrm{X}_{1}$ with $\mathrm{X}_{3}$ & 1,511 & 0,068 & Linier & 46,041 & 0,000 & Significant \\
3 & $\mathrm{X}_{1}$ with $\mathrm{X}_{4}$ & 1,223 & 0,230 & Linier & 35,355 & 0,000 & Significant \\
4 & $\mathrm{X}_{2}$ with $\mathrm{X}_{4}$ & 1,385 & 0,109 & Linier & 23,852 & 0,000 & Significant \\
5 & $\mathrm{X}_{3}$ with $\mathrm{X}_{4}$ & 1,031 & 0,442 & Linier & 23,872 & 0,000 & Significant \\
\hline
\end{tabular}

Information:

$\mathrm{X}_{1}=$ Use of Information and Communication Technology

$\mathrm{X}_{2}=$ Career Development

$\mathrm{X}_{3}=$ Work Environment

$\mathrm{X}_{4}=$ Job Stress

\subsubsection{Testing of Research Hypotheses}

Testing the analysis requirements in this study has been fulfilled, so that the research hypothesis testing can be continued to prove and provide answers to the problems that have been formulated in the study.

Table 4. Summary of Results of Correlation Coefficient Calculations, Path Coefficients and Meanings

\begin{tabular}{ccccccc}
\hline No & Variabel & Coefficient Corelation* & Coefficient Lane & Counted & Signicant & Information \\
\hline 1 & $\mathrm{X}_{1}-\mathrm{X}_{2}$ & $\boldsymbol{r}_{12}=0,513$ & $\boldsymbol{\rho}_{21}=0,513$ & 6,547 & 0,000 & Significant \\
2 & $\mathrm{X}_{1}-\mathrm{X}_{3}$ & $\boldsymbol{r}_{13}=0,525$ & $\boldsymbol{\rho}_{31}=0,525$ & 8,605 & 0,000 & Meaningful lane \\
3 & $\mathrm{X}_{1}-\mathrm{X}_{4}$ & $\mathrm{r}_{14}=-0,476$ & $\boldsymbol{\rho}_{41}=-0,268$ & $-2,677$ & 0,008 & Meaningful lane \\
4 & $\mathrm{X}_{2}-\mathrm{X}_{4}$ & $\boldsymbol{r}_{24}=-0,406$ & $\boldsymbol{\rho}_{42}=-0,202$ & $-2,237$ & 0,027 & Meaningful lane \\
5 & $\mathrm{X}_{3}-\mathrm{X}_{4}$ & $\boldsymbol{r}_{34}=-0,406$ & $\boldsymbol{\rho}_{43}=-0,198$ & $-2,169$ & 0,032 & Meaningful lane \\
\hline
\end{tabular}

*All Coefficient Corelation Significance ( $\mathrm{t}_{\text {hitung }}$ ) are bigger than ari $\mathrm{t}_{\text {tabel }}(5 \%)=1,645$

Information:

$\mathrm{X}_{1}=$ Use of Information and Communication Technology $\mathrm{X}_{3}=$ Work Environment

$\mathrm{X}_{2}=$ Career Development $\quad \mathrm{X}_{4}=$ Job Stress

\section{Conclusion}

Based on the proof of the hypothesis proposed in this study, further conclusions can be put forward as follows:

a. Utilization of Information and Communication Technology has a positive direct effect on the Career Development of teachers in SD Negeri Cluster 1 and 3 Bandar Subdistrict, Bener Meriah Regency, Aceh Province. In other words, the better the utilization of Information and Communication Technology, the better the Career Development of Teachers of Primary Schools in Groups 1 and 3 of Bandar Subdistrict, Bener Meriah District, Aceh Province.

b. Utilization of Information and Communication Technology has a positive direct effect on the working environment of teachers in SD Negeri Cluster 1 and 3 in Bandar Subdistrict, Bener Meriah Regency, Aceh Province. In other words, the better 
the utilization of Information and Communication Technology, the better the Teacher's Work Environment SD Negeri Cluster 1 and 3 Bandar Subdistrict, Bener Meriah Regency, Aceh Province.

c. Utilization of Information and Communication Technology has a direct negative effect on teacher work stress in $S D$ Negeri Cluster 1 and 3 in Bandar Subdistrict, Bener Meriah Regency, Aceh Province. In other words, the higher the utilization of Information and Communication Technology, the decreasing Teacher Job Stress $S D$ Negeri Cluster 1 and 3 Bandar Subdistrict, Bener Meriah Regency, Aceh Province.

d. Career Development has a direct negative effect on teacher work stress in SD Negeri Cluster 1 and 3 Bandar Subdistrict, Bener Meriah Regency, Aceh Province. In other words, the better the teacher's career development, the lower the teacher's work stress $S D$ Negeri Group 1 and 3 Bandar District Bener Meriah District, Aceh Province.

e. Work Environment has a direct negative effect on teacher work stress $S D$ Negeri Cluster 1 and 3 Bandar Subdistrict, Bener Meriah Regency, Aceh Province. In other words, the higher the teacher's working environment, the lower the teacher's work stress SD Negeri cluster 1 and 3 Bandar sub-district, Bener Meriah district, Aceh province

\section{References}

[1] Gibson, James, and Catwirght, Organization: Behavior, Structure, Process. Jakarta: Erlangga, 1987.

[2] National Safety Council, Stress Management. Jakarta: EGC, 2004.

[3] S. P. Siagian, Manajemen Sumber Daya Manusia. Jakarta: Bina Aksara, 2014.

[4] S. P. Robbins, Organizational Behavior. New Jersey: Preticeh-Hall, 1998.

[5] G. Saydam, Human Resource Management: A Micro Approach (in Question and Answer). Jakarta: Djambat, 2000.

[6] S. Samsudin, Manajemen Sumber Daya Manusia. Bandung: Pustaka Setia, 2010.

[7] A. S. Nitisemito, Personel Management and Human Resource Management. Jakarta: Ghalia Indonesia, 1992.

[8] Sedarmayanti, Human Resources and Work Productivity. Bandung: Mandar Forward, 2001. 